Article

\title{
The Impact of Human Interventions and Changes in Climate on the Hydro-Chemical Composition of Techirghiol Lake (Romania)
}

\author{
Carmen Maftei ${ }^{1}$, Constantin Buta ${ }^{2}$ and Ionela Carazeanu Popovici ${ }^{3, *}$ \\ 1 Civil Engineering Faculty, Transilvania University of Brasov, 29 Eroilor Blvd, 500036 Brașov, Romania; \\ carmen.maftei@unitbv.ro or cemaftei@gmail.com \\ 2 Civil Engineering Faculty, Ovidius University of Constanta, 124 Mamaia Blvd, 8700 Constanta, Romania; \\ buta.constantin@univ-ovidius.ro or costi_buta@yahoo.com \\ 3 Applied Science and Engineering Faculty, Ovidius University of Constanta, 124 Mamaia Blvd, \\ 8700 Constanta, Romania \\ * Correspondence: icarazeanu@univ-ovidius.ro; Tel.: +40-74-888-5377
}

Received: 18 May 2020; Accepted: 21 July 2020; Published: 12 August 2020

\begin{abstract}
The aim of this study is to establish the potential effect of changes in climate and anthropic interventions made over time on the hydro-chemical properties of the Techirghiol Lake. Located in the littoral region of the Black Sea, Techirghiol Lake is the most hypersaline lake of Romania-well-known for the therapeutic properties of the saline water and sapropelic mud. Long-term time series of salinity and water level were investigated in relation to the lake water inputs (precipitation, overland flow and groundwater), to chemical parameters ( $\mathrm{pH}, \mathrm{DO}$ and BOD5) and also to the hydraulic works designed and built in the region. The obtained results reveal a degradation of this ecosystem in the period of 1970-1998, when the extensive irrigation practice in the proximity of the lake had a negative effect on the water budget of Techirghiol Lake (an increased freshwater input through runoff and seepage), followed by a major decrease of the lake's salinity.
\end{abstract}

Keywords: human intervention; changes in climate; salty lake

\section{Introduction}

Climate change has a considerable impact on ecosystems, affecting air temperature, the amount of precipitation, the frequency and intensity of extreme events, the sea level, etc. In the past decades, many studies have been conducted on saline lakes which show not only the importance of saline lakes in the economies, but also the impact of climate change on the water level and chemical content [1-3]. The study conducted by Valero-Garces et al. [4] on the saline lakes from Spain highlights the influences of agricultural practices, particularly of irrigation, on the lake's hydrological behavior. Webster et al. [5] have examined the influence of the increasing trend of drought on semiconservative cations, $\mathrm{Ca}^{+}$and $\mathrm{Mg}^{+}$, in seven lakes from Northern Wisconsin, and have concluded that the high evaporation rates, combined with the decreased amount of precipitation, caused an increase of cation concentrations in all lakes. Recent studies conducted in Poland concerning the influence of many factors (climatic, hydrologic, morphometric) on lake temperatures have shown that the lake response to factor modifications depends on the local conditions and lake characteristics [6,7]. All over the world, the studies conducted had the same conclusion: the saline lakes are threatened by climate change and by the various anthropogenic activities, which lead to dramatic changes in lakes chemistry and dynamics [1,8-10]. The analysis of water chemistry in relation to environmental factors allows a better understanding of the process variability and is very useful for researchers and deciders in the field of water management and monitoring [7,11]. 
This study presents an analysis of the potential effect of changes in climate and anthropic interventions on the hydro-chemical properties of Techirghiol Lake, located in the littoral region of the Black Sea. We have combined historical knowledge of human activities and management of the lake and the surrounding areas with a compilation of data detailing precipitation, river discharge and more. The first part of this study is focused of the study area and its main characteristic elements (climatic, geologic, hydrogeologic and hydrologic). In the second part, the chemical composition and water quality of Techirghiol Lake were investigated in the context of climatic and anthropogenic impact using Romanian methodologies and regulation.

\section{Materials and Methods}

This section is divided in two parts: the first part is dedicated to the presentation of the study area and its main characteristic elements (climatic, geologic, hydrogeologic, hydrologic and lake water chemistry) and the second one features the methods used.

\subsection{Study Area and Its Characteristics}

Techirghiol Lake is a result of the latest paleogeographic evolution of the Black Sea, dictated by the evolution of the sea level over time [12-14], which contributed to the development of the present shoreline. Accordingly, the coastal development and the sand-belt formation have completely isolated Techirghiol Lake. Located on the Black Sea coast, $16 \mathrm{~km}$ south from Constanta City (Figure 1), Techirghiol Lake is mainly known for the curative properties of its sapropelic mud and hypersaline water. Here, a veritable tourism economy has developed since 1899, around balneological treatment and medical rehabilitation.

The catchment area of Techirghiol Lake is situated in the South Dobrogea Plateau, having a surface of approximately $160 \mathrm{~km}^{2}$. The lake is $8 \mathrm{~km}$ long, with the maximum width of $4.4 \mathrm{~km}$ and a water depth varying between $1.5 \mathrm{~m}$ and $9.5 \mathrm{~m}$. The maximum water depth was recorded at $9.75 \mathrm{~m}$ and the average water depth is $3.6 \mathrm{~m}$ [15].

The studied area has a relief consisting in a not very tall plateau $(+70-80 \mathrm{~m})$, with a slope which descends to the sea that ends abruptly with a 30-m-high cliff (Figure 1).

The Techirghiol Lake area is situated in a temperate-continental climatic zone, which is influenced by the Black Sea. The region is characterized by an average annual temperature of approximately $11^{\circ} \mathrm{C}$ and an annual rainfall amount of about $400 \mathrm{~mm}$ [16]. The data recorded at Constanta meteorological station were chosen in order to analyze the influence of climatic parameters on the lake's behavior.

From a geological point of view, Techirghiol Lake area is situated in the South Dobrogea Plateau. The South Dobrogea Plateau basement layer consists of granitic gneiss and crystalline shale. Above this basement layer, this sector integrates three main sedimentary geological systems: Sarmatian limestone, red clay mixed with gypsum and loess deposits. The presence of faults and the sedimentary structure of Techirghiol Lake area have determined the development of several deep complex aquifers, among which a free surface aquifer situated in Sarmatian limestone and a pressure aquifer located in limestone and dolomitic deposits [17].

From the hydrological point of view, Techirghiol Lake is situated at the confluence of several important valleys (Figure 2), most of them with an intermittent flow. In 1910, Pascu [18] identified four important valleys that drained the Techirghiol catchment: Carlichioi (Biruinta) Valley, Techirghiol Valley, Muzurat (today Urlichioi) valley and Tuzla Valley. In 1976, Breier identified three important valleys: Techirghiol, Tuzla and Carlichioi (Biruinta) valleys (Figure 2). Today, the hydrological regime of the main hydrographic networks is very different, and the important valleys are barred by different hydraulic works (dams and penstock) in order to prevent the entrance of freshwater in the lake (Figure 2). The hydrological features of the lake are related to the evolution of the lake's level, which is strongly influenced by the aquifer input and by the discharge of the valleys. 


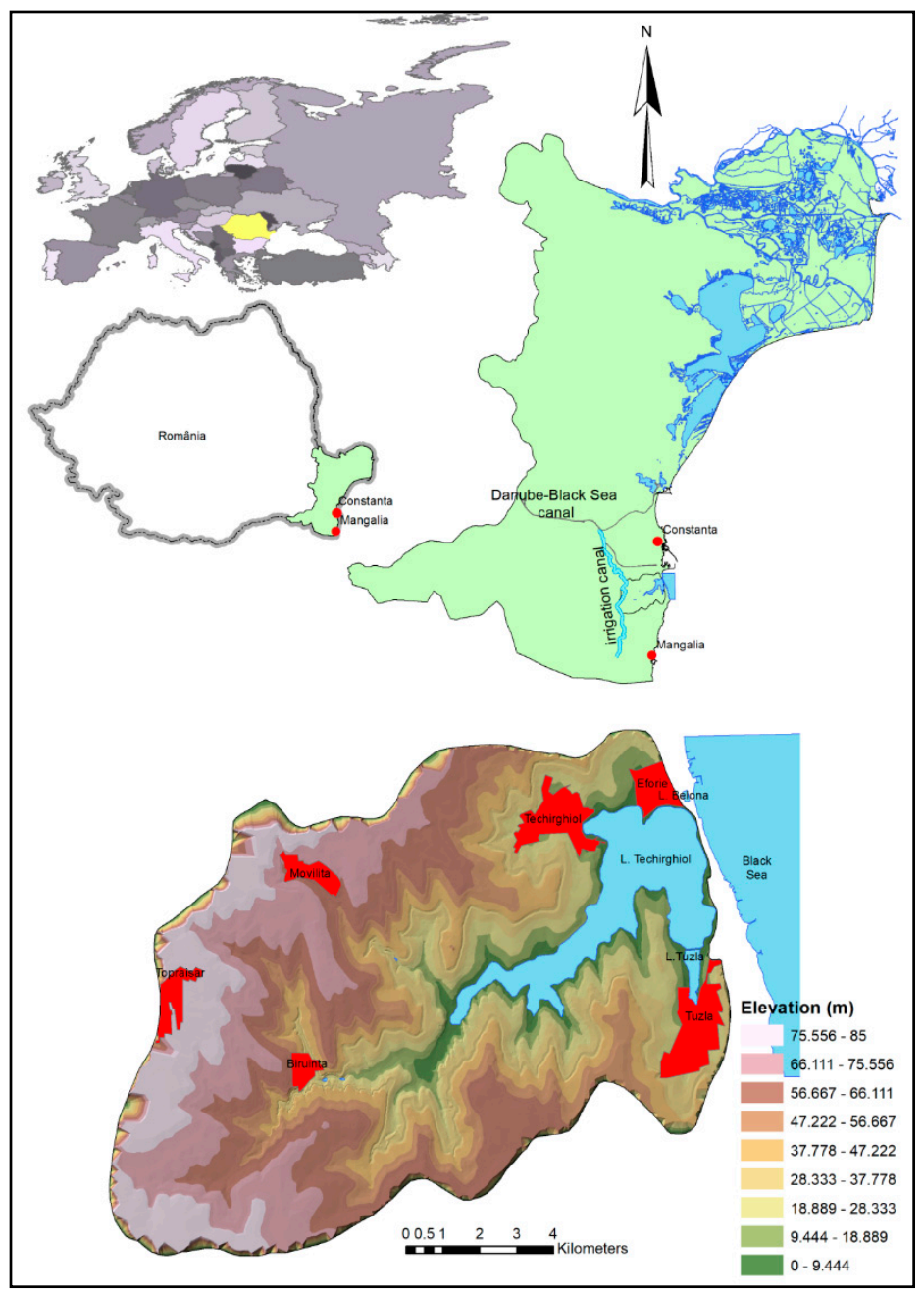

Figure 1. Location of Techirghiol Lake.

Techirghiol Town is well known as a balneotherapy center due to the importance of sapropelic mud and saline water used in therapeutic treatment. Two important centers have been developed here: the Techirghiol Balneotherapy Center (in 1899) and the Eforie Balneotherapy Center (in 1923). To sustain the economic development of this area, water supplies for the localities were established around the lake in the period of 1953-1956. During this period, wastewater was discharged into the lake. Since 1956, wastewater has been treated by a wastewater treatment plant built in South Eforie Town. Treated water is discharged first into the Tuzla pond, and then into Techirghiol Lake. In 1969, important hydraulic works were made in the Lake Techirghiol catchment: (i) $12 \mathrm{~km}$ west of the lake is situated the principal irrigation channel "Basarabi-Negru Voda", which loses $60 \%$ of the water through infiltration; (ii) $8 \mathrm{~km}$ north of the lake is located the "Danube-Black Sea"-navigable channel. In 1971, an irrigation system built in the area was put into operation. Since 1976, water from the treatment plant has been introduced into the irrigation system. In order to eliminate the effects of irrigation on the lake's parameters-and due to the fact that the stoppage of irrigation was incompatible with the state policies of that period (Dobrogea Region being an arid area where crops cannot grow in optimal conditions without irrigation) - the National Water Administration took at that time a series of measures to limit the effects of irrigation. First, in 1972-1973 and then in 1983, water from the lake was pumped directly into the sea. The protection works were carried out in three stages, which were completed in 2005. In the first stage during 1977-1979, all groundwater observation drillings were equipped with pumps and the wastewater discharge into the lake was forbidden. During the second stage (1980-1983), another 11 groundwater drillings were equipped 
with pumps (intercepted water was used for water supply) and on the rivers Biruinta, Izvoarele and Gospodarie were built dams (behind the dams were placed two pumping stations). The third stage began in 1988 with the construction of the Techirghiol dam-which ended in 1991—and the drainage of the freshwater from behind the dam through a pipe (diameter of $1400 \mathrm{~mm}$ and a length of $9.1 \mathrm{~km}$ ) into Belona Lake (near Eforie Town). A number of small dams were also built in all of the small valleys to intercept the freshwater and evacuate it. As a result of all these hydraulic works, the water surface of Techirghiol Lake decreased. Now, the studied area is divided into three zones: the freshwater area-Biruinta, Izvoarele, Gospodariei lakes, the brackish water area-Zarguzon Lake and the saline water area-Techirghiol Lake (Figure 2).

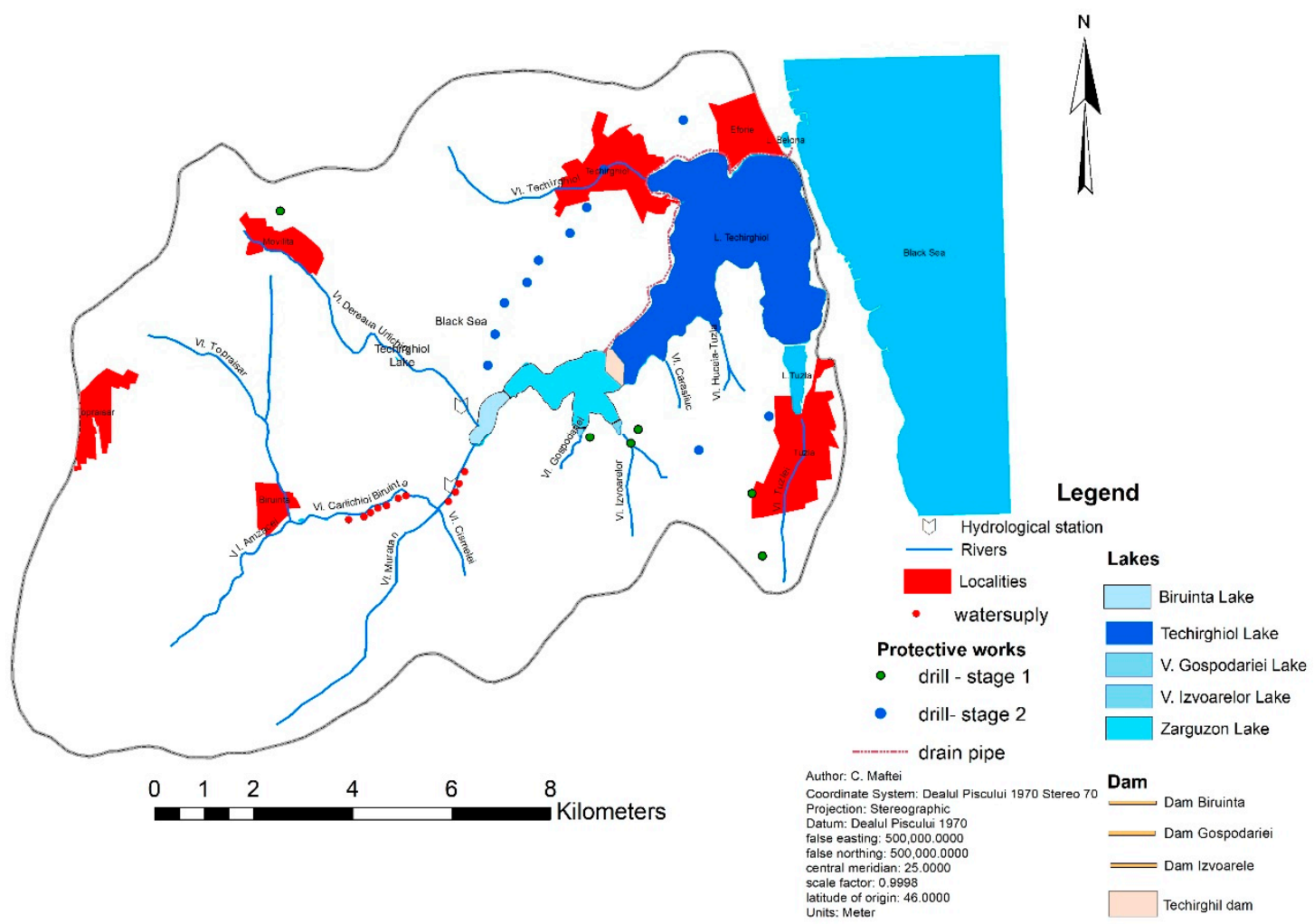

Figure 2. Digital Elevation Model of Techirghiol Lake basin.

The main characteristics investigated in this study which influence the Techirghiol water budget are annual precipitation, overland flow and groundwater. These data are obtained from government reports spanning the period of 1953-2015.

The lake water chemistry parameters investigation that covers salinity, $\mathrm{pH}$, dissolved oxygen (DO) and biochemical oxygen demand (BOD) is based on the data provided by the Romanian Water Administration-Dobrogea Littoral Branch. The data were obtained from various sources, such as government reports, old published papers or unpublished reports [19-25]. The systematic measurement started in 1993, but several government works [21,22] provide some values for these chemical parameters before this period. The investigated period is 1993-2015.

\subsection{Methodologies}

The methodology used for the analysis of hydrological data is described by Kundzewicz and Robsson [26] and is based on the following steps: (1) obtainment and preparation of a suitable dataset; (2) exploratory analysis of the data and (3) application of statistical tests. Concerning the first step the datasets were performed by INHGA (Romanian National Institute of Hydrology and Water Management), so they are expected to be reliable and free of gross errors, given that the gauging process 
was supervised by professional personnel. A set of statistical tests which detect step-change in the mean or median of a series was used in previous studies [16,27-31], namely Pettitt, Buishand test, Lee and Heghinian test. In order to detect multiple changes in time series data, the segmentation procedure of Hubert and changing point analysis (based on CUSUM procedure) were used and presented in previous studies we have already mentioned. Some results will be provided in the following paragraph in correlation with other investigated parameters.

The chemical composition and water quality of Techirghiol Lake were investigated in the context of climatic and anthropogenic impact using Romanian methodologies and regulation [19,20]. According to the methodology, Techirghiol Lake is a heavily modified water body. In this respect, for each chemical element mentioned above, the methodology establishes the limits and the ecological status/potential. Three ecological potential classes are identified for heavily modified water bodies: (i) maximum ecological potential (PEM), (ii) good ecological potential (PEB), (iii) moderate ecological potential (PEMo). The range of variation of each class was developed by a series of research institutes and experts.

\section{Results and Discussion}

To determine the effects of changes in climate in the Dobrogea region and thus on the behavior of Lake Techirghiol, the results obtained in the studies previously mentioned are capitalized [16,27-30]. To conclude: (T-temperature) a break point is identified in 1997-1998 and the mean annual temperature increased by $0.8^{\circ} \mathrm{C}$ in the 1997-2015 period-compared to the period of 1953-1997, which is in concordance with the estimation made for Europe by different reports [32-35]. (P-precipitation) Figure 3 shows the variability of rainfall amount from 1953 to 2015.

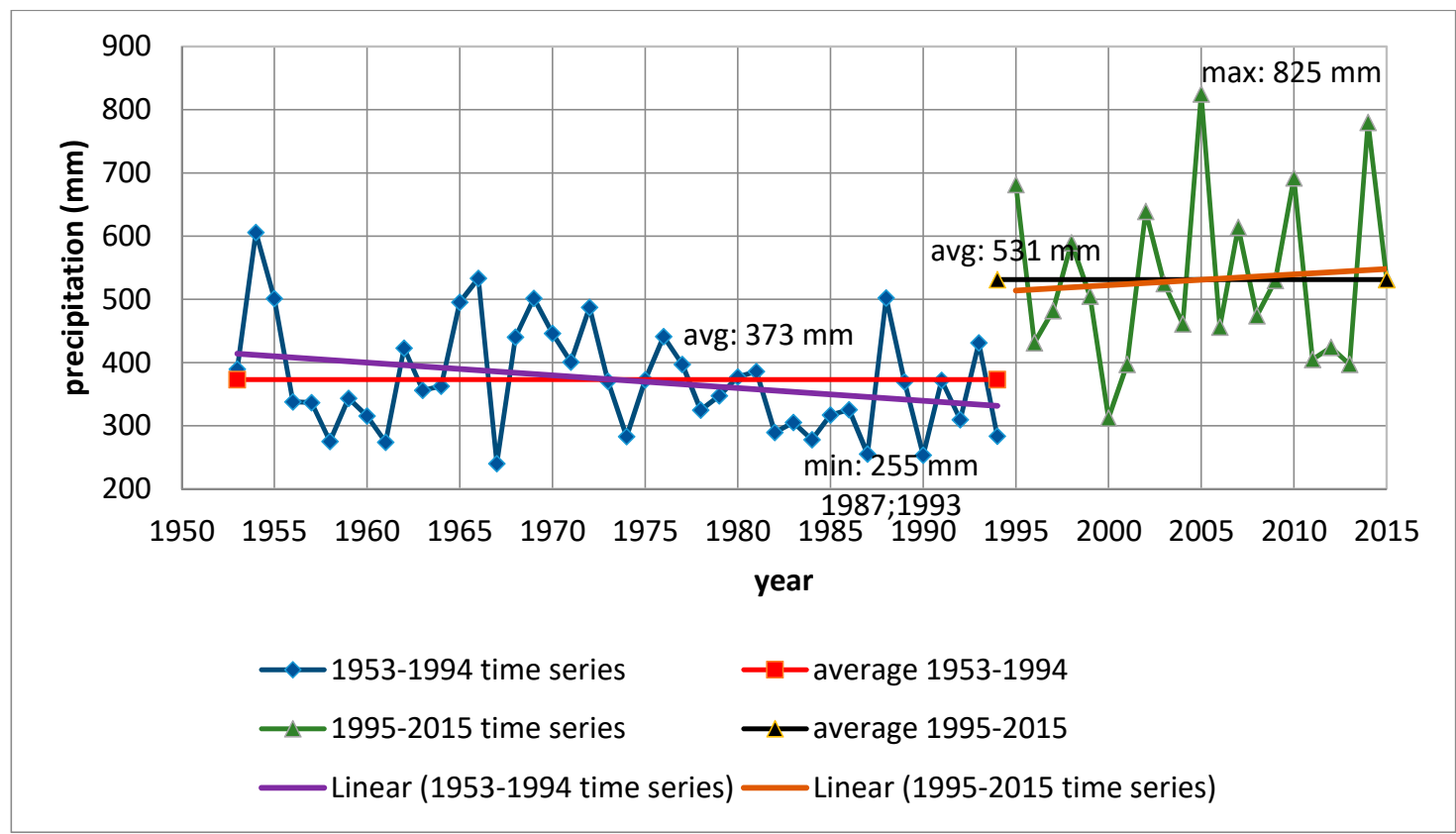

Figure 3. Precipitation variation (1953-2015 period).

The annual precipitation value varies between a minimum value of 255 and a maximum value of $825 \mathrm{~mm}$. The multiannual rainfall value for the entire study period is $425 \mathrm{~mm}$. According to [27,35], precipitations have a break point in 1994. For the period of 1953-1994 we observe a decreasing trend and after it an increasing trend (Figure 3), and the mean annual precipitation increased from 373 to 531 mm. Starting with 1995, the annual precipitation has been above the multiannual precipitation except the following years: 2000 and 2001, 2011 and 2013. 
The overland flow $(\mathrm{OvF})$ is presented in Figure 4. This flow is provided by two major river valleys: Biruinta and Urlichioi.

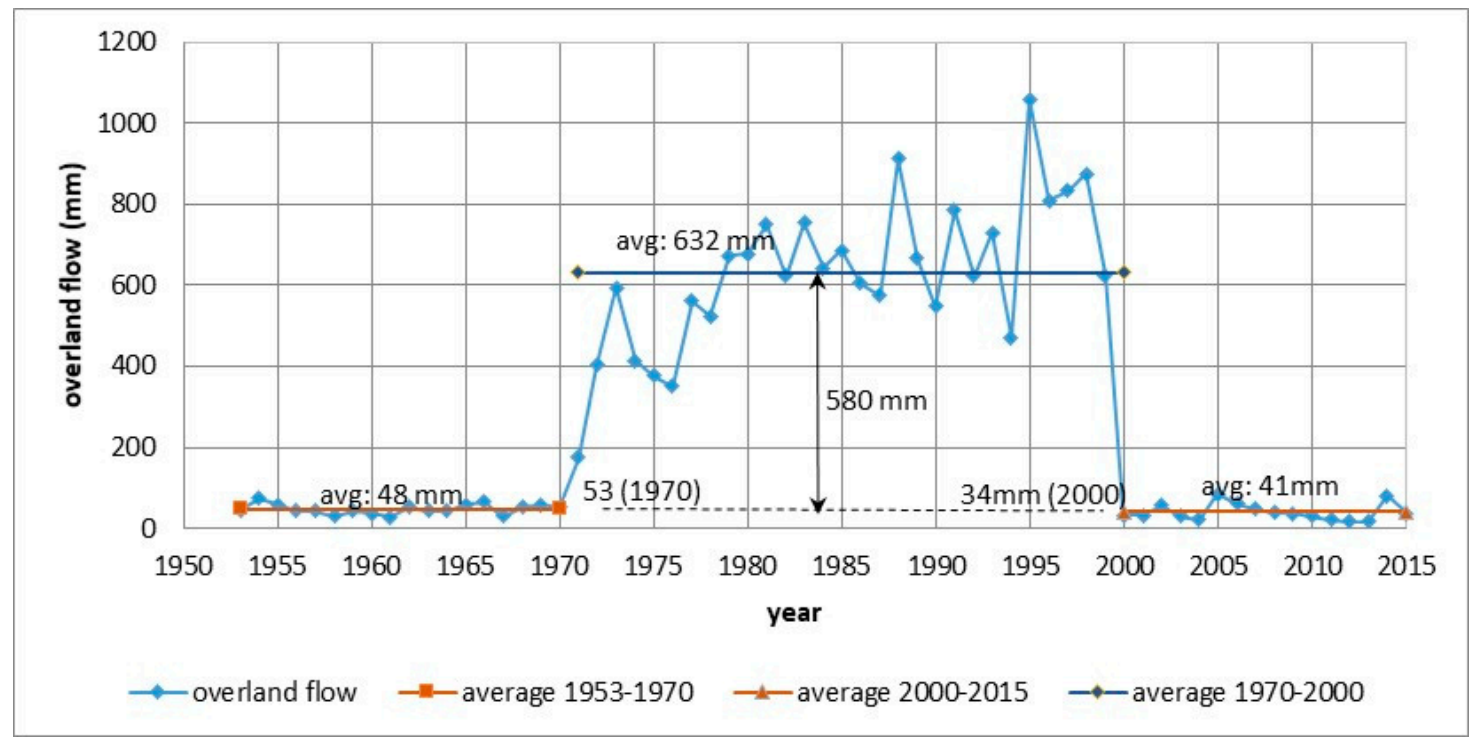

Figure 4. Overland flow variation [35].

According to [35], the overland flow time data series presents three break points in 1971, 1978 and 2000. The first was observed in 1970 when the irrigation system became operational (in the period of 1953-1970 the average overland flow rate was $48 \mathrm{~mm}$ ). The third one is observed in 2000. After 2000 the overland flow value returned to the average value of the 1953-1970 period (41 mm). We consider that this breakpoint is in relation to anthropic intervention: 1997-1998 was the last time freshwater was introduced into the main irrigation channel that crosses the lake's catchment: in 1991, the Techirghiol dam entered into operation. In the period of 1970-2000, the average overland flow increased to $632 \mathrm{~mm}$ (the increase was about 14 times relative to the previous period- $580 \mathrm{~mm}$ ). However, the maximum value of overland flow was recorded in 1995 (1058 mm).

The groundwater supply (GW) is presented in Figure 5. The values varied between a minimum value of $98.2 \mathrm{~mm}$ (2015) and a maximum value of $1206.9 \mathrm{~mm}$ recorded in 1985. It is noted that the groundwater input time series is divided in three subseries [35]. During the period of 1953-1969, the groundwater input value did not exceed $534 \mathrm{~mm}$. Since 1970, this value has increased on average about 1.5 times. The average value for the period of 1970-2000 was $754.7 \mathrm{~mm}$. Since 2000, as a result of finalizing the works proposed in the third stage, the groundwater input value decreased, reaching the minimum value $(98 \mathrm{~mm})$ in 2015.

In Figure 6 is represented the variation of the main inputs $(P+\mathrm{OvF}+\mathrm{GW})$ in Techirghiol Lake as average per period. The periods marked by the human interventions and the breakpoint in precipitation data series is highlighted. Analyzing the results obtained we could conclude that the hydraulic works built until 1970, especially the irrigation system, changed the water budget of Techirghiol Lake after 1971. In the 1971-1978 periods, the overland flow increased from 46 to $411 \mathrm{~mm}$ on average. In this period, the overland flow represented $31 \%$ of the total budget. The first protective works performed in 1977-1979 did not influence the overland flow and groundwater regime in the sense that it diminished. On the contrary, in the period of 1979-1983 (only five years), the average values of these parameters increased and represented $80 \%$ of the total water budget. We could conclude that the hydraulic works did not have the expected effect, given the average values of groundwater increase from 692 to $1040 \mathrm{~mm}$ approximately, in the period of 1984-1986. 


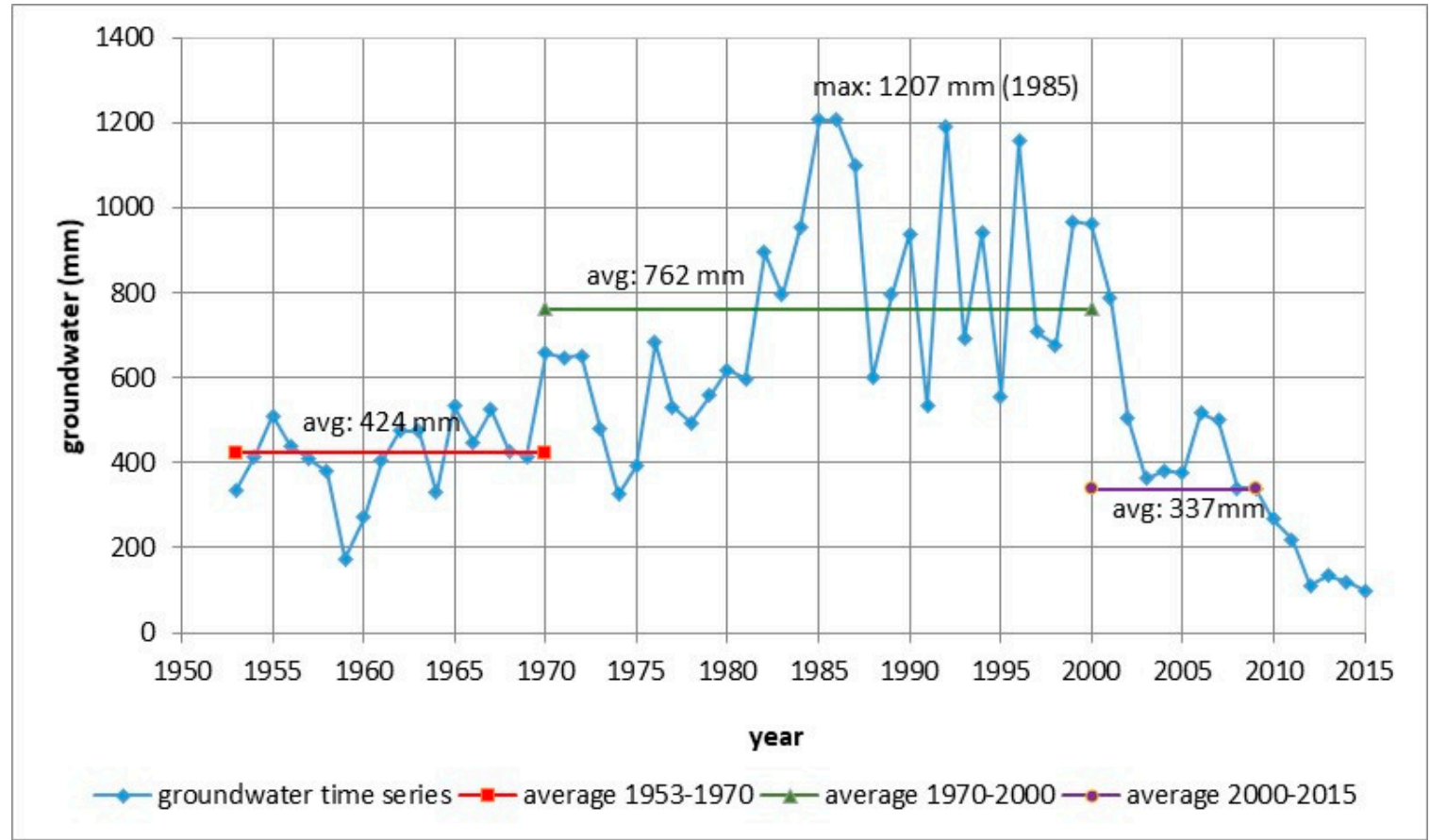

Figure 5. Groundwater input variation.

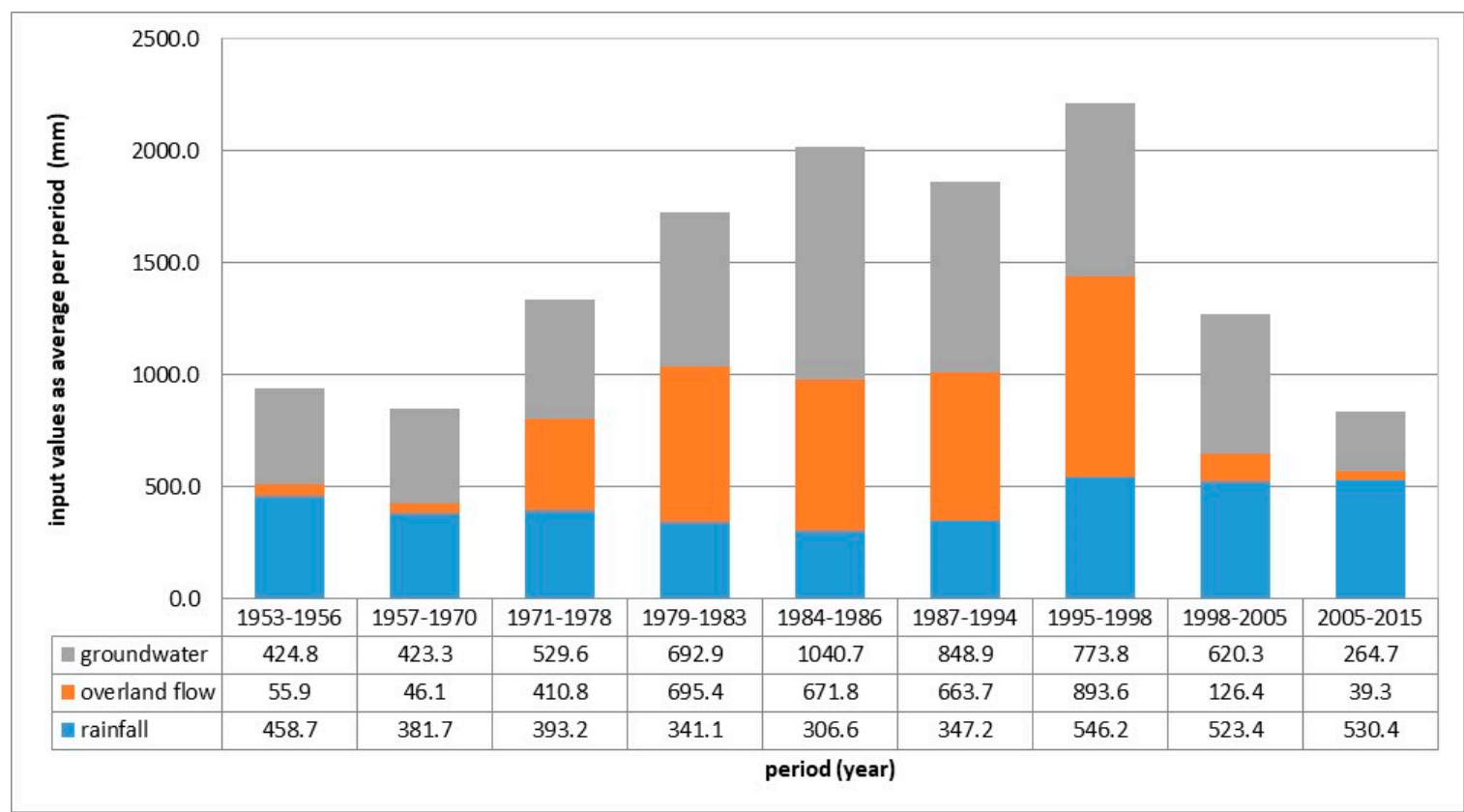

Figure 6. Variation of the min input values (average/period) in the Techirghiol water budget.

The hydraulic works performed in the period of 1983-1986 failed to bring new improvements to the Techirghiol water budget. The average values of overland flow are maintained at the level of the period of 1987-1994, while the average values of groundwater flow have decreased by $200 \mathrm{~mm}$. As previously mentioned, starting with 1995 the value of precipitation increased. In the following period, the average values are maintained at $43 \%$ of the total water budget. The protective works started in 1988 and were finalized in 1991 and 2005, the stoppage of the irrigation activity (1998) causing an improvement of the water budget: the average of overland flow decreased to $39 \mathrm{~mm}$ and the average groundwater value to $264 \mathrm{~mm}$. 
Figure 7 shows the evolution of the water level in the lake between 1953 and 2015; some isolated measurement data are from 1909.

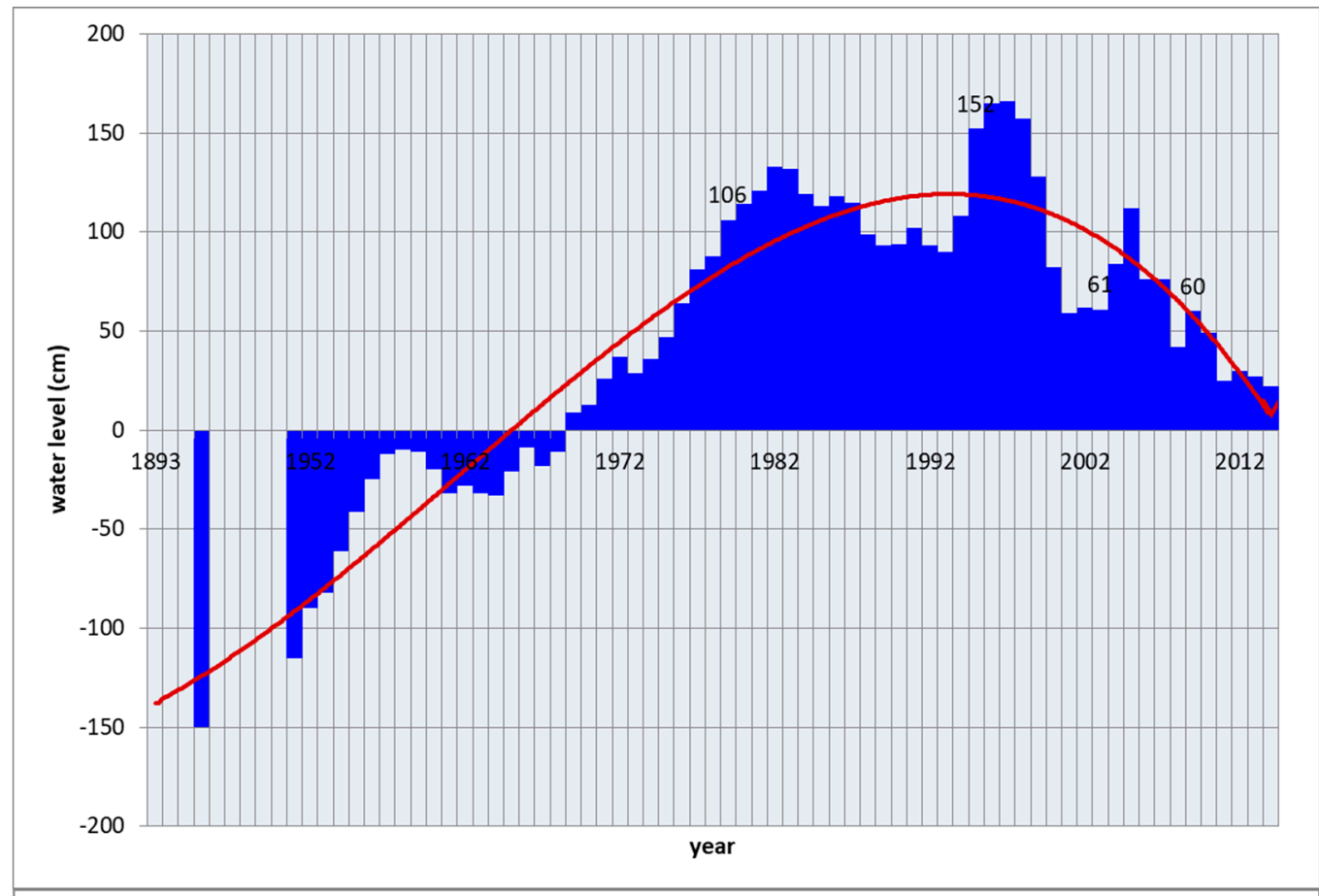

(a)

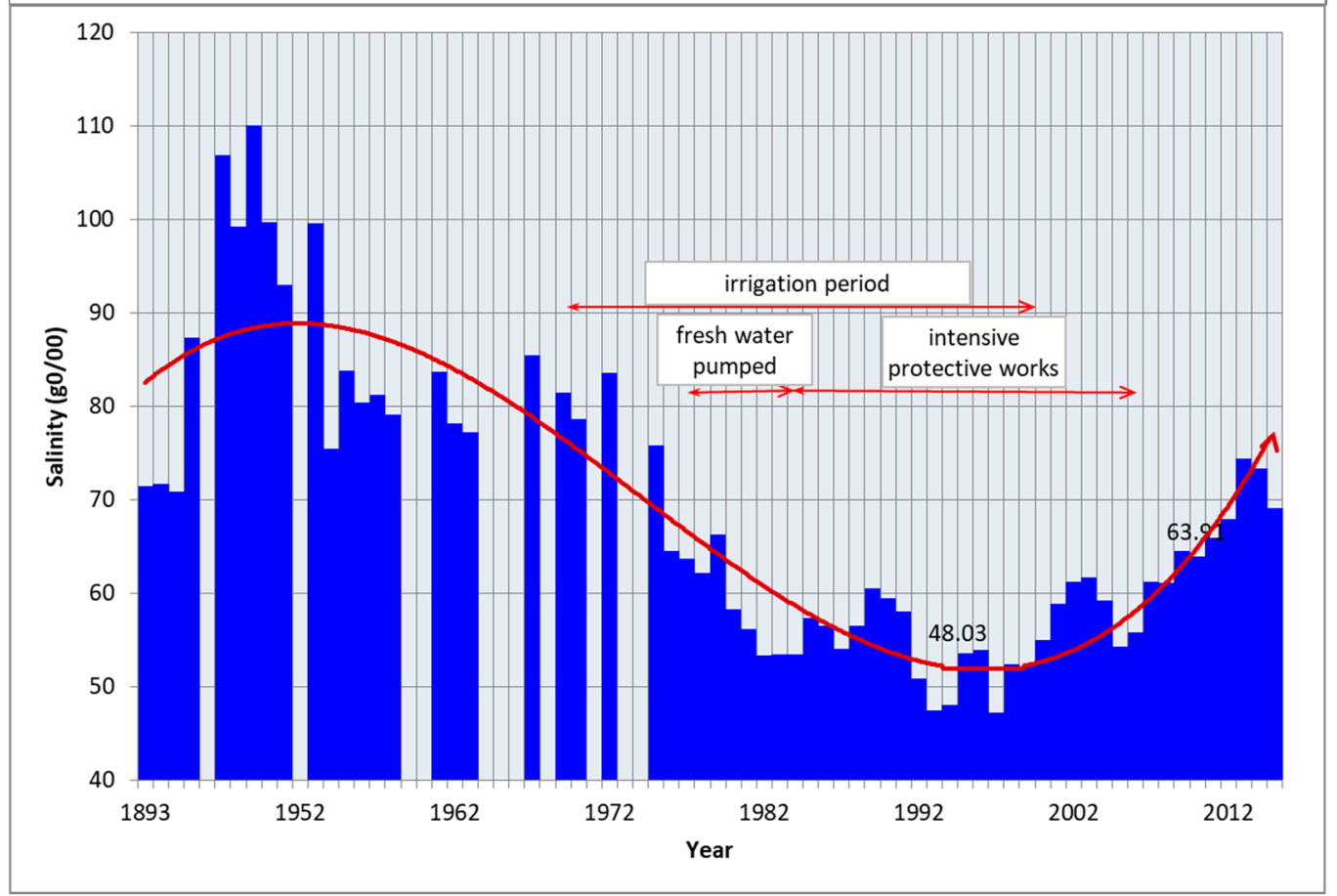

(b)

Figure 7. Water level and salinity evolution of Techiorghiol Lake under changes in climate and anthropic impact. (a) Salinity; (b) water level.

It can be seen that in the investigated period, water levels in the lake rose from $-150 \mathrm{~cm}$ to $+153 \mathrm{~cm}$ (the measurements are relative to the Black Sea level). Between 1909 and 1952 the water level in the lake increased by an average of $0.8 \mathrm{~cm} /$ year, between 1954 and 1966 the water level increased by $6 \mathrm{~cm} / \mathrm{year}$. Since 1970 the water level in the lake has become positive $(+9 \mathrm{~cm})$, relative to the Black Sea reference level $( \pm 0.00)$. The increase in water level in the lake was accentuated after 1970 , the average value 
being $9 \mathrm{~cm} /$ year, as a result of land irrigation of the lake's catchment. From 1965 to 1989, the water level steadily increased to $133 \mathrm{~cm}$, and in the period of 1996-1999 the level reached the highest values $(+153 \mathrm{~cm})$. As a result of the hydraulic works, there has been a trend of increasing the water level in the lake, combined with the decrease of the salinity of the water. Since the land irrigation was stopped (in 1998) the lake's water level has been slowly decreasing in the following years, in 2015 the level being $22 \mathrm{~cm}$ above Black Sea level (Figure 7).

Increases of water inputs led to the severe decrease of salinity around $47 \mathrm{~g} \%$ in 1992 and 1997. In the irrigation period of 1970-1997, even if a number of protective measures were introduced, a substantial increase in salinity was not possible. After the irrigation was stopped (1998), the salinity began to increase, reaching the value of $70 \mathrm{~g} \%$ o (in 2015).

The changes caused by the increase of the freshwater inflow and the decrease of salinity caused quantitative changes in the lake's biotic community, especially in some organisms involved in the process of peloidogenesis. Some studies [21,36] reveal a decrease of green algae Cladophora vagabunda from 81.49 tons in 1978 to 42 tons in 1981. It is known [37] that the optimal salinity values in which this alga can develop are 73-83 g/L. This situation began to improve in 1987 when the second stage of protective works became operational. The completion of protective work (in 2005) and closure of the irrigation system (in 1998) has led to ecosystem regeneration.

The water of Techirghiol Lake is alkaline; the average value for $\mathrm{pH}$ is 8.3 (Figure 8). Normally, there is a direct relationship between water $\mathrm{pH}$ and salinity; a higher value of $\mathrm{pH}$ is given by the high content of mineralization. Even if the salinity of Techirghiol Lake waters decreased to a value of $47 \mathrm{~g} \%$, the $\mathrm{pH}$ value of the waters was never under the value of 7.9. Figure 8 shows that the lake water $\mathrm{pH}$ is situated in the range 6.5-9 pH, more accurate under 8.5 units, except the values from 1999 and 2000.

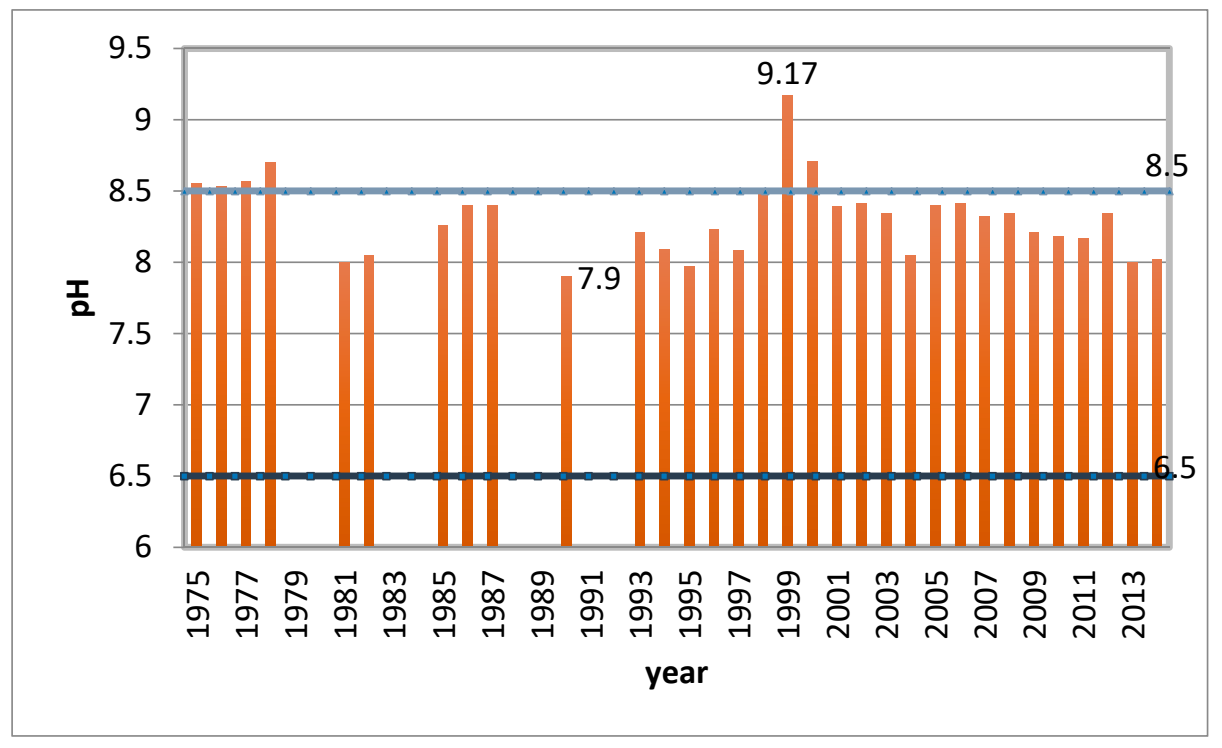

Figure 8. Variation of $\mathrm{pH}$ over time.

Figure 9 shows the variation of the dissolved oxygen (DO) time data series. It can be seen that the dissolved oxygen (DO) varies between 11 and $4.04 \mathrm{mg} / \mathrm{L}$. In the period of 1975-1990 the DO values were over $8 \mathrm{mg} / \mathrm{L}$ and lake water could be included in the PEB category. The DO values have decreased after 1990 from an average of $8.91 \mathrm{mg} / \mathrm{L}$ to $6.24 \mathrm{mg} / \mathrm{L}$. Correspondingly, the ecological potential has decreased, lake water could be included in the PEB/PEMo category. Three exceptions could be considered: 2009, 2013 and 2014, when water could be included in the PEM/PEB category. 


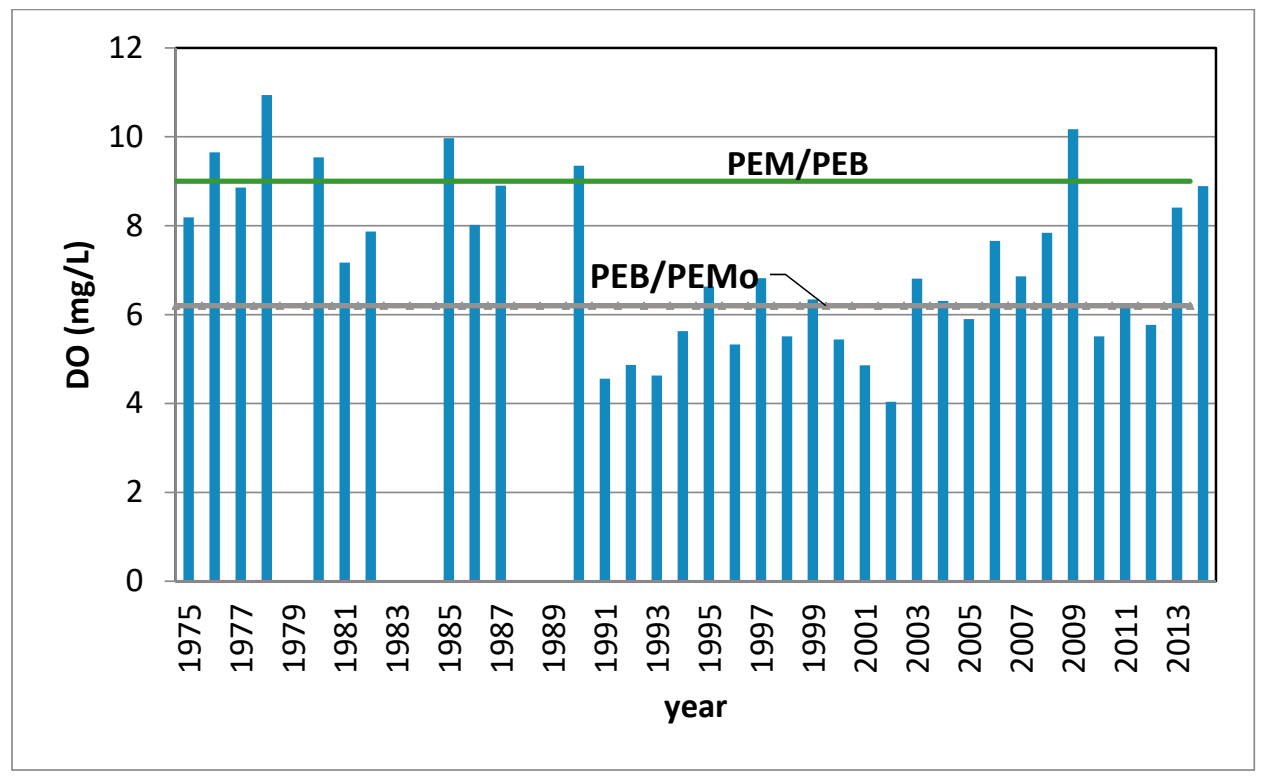

Figure 9. Variation of dissolved oxygen (DO).

The biologic oxygen demand (BOD) represents the mass concentration of dissolved oxygen consumed by microorganism or measures the chemical oxidation of inorganic matter in a given time (e.g., BOD5 stands for five days test). BOD5 affects the DO values. A greater BOD5 value means less oxygen for the microorganism's activity. The variation of this indicator is presented in Figure 10. Generally during the 1975-1993 period, the BOD5 values were between $3 \mathrm{mg} / \mathrm{L}$ and $6 \mathrm{mg} / \mathrm{L}$ and the lake water could be included in the PEM/PEB ecological potential category. After 1994 the BOD5 values have generally increased above $6 \mathrm{mg} / \mathrm{L}$. In fact, during the period of 1994-2012, the average was three times higher than the average of the previous period.

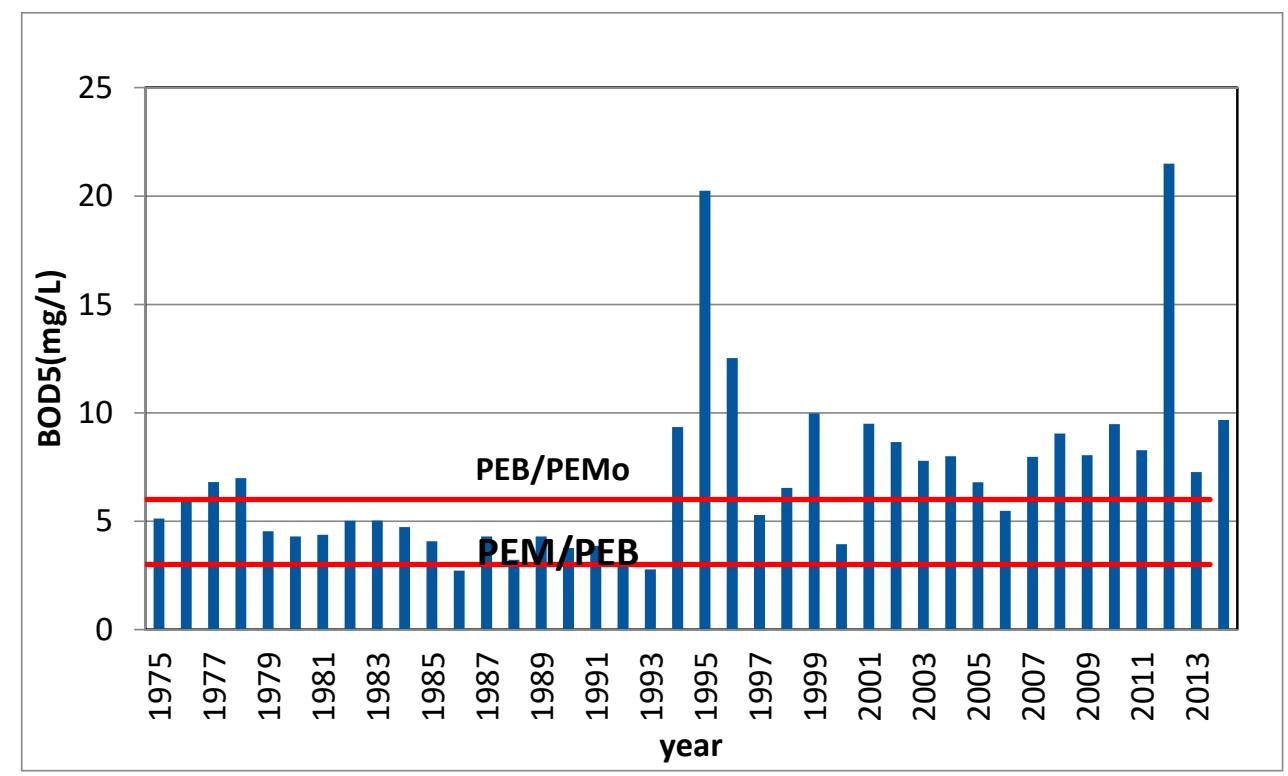

Figure 10. Variation of Biochemical oxygen demand (BOD).

The ecological potential of Techirghiol Lake from the point of view of the investigated elements varies throughout the period investigated (Table 1). It can be seen that Techirghiol Lake water could be included in the PEB/PEM category for the period of 1975-1990 (in this period, a larger quantity 
of freshwater was introduced via the irrigation system). After 1990 (1993 for BOD5) lake water was included in the PEB/PEMo category.

Table 1. Ecological Potential Variation.

\begin{tabular}{ccc}
\hline Water Chemistry Elements & Ecological Potential & Period \\
\hline $\mathrm{pH}$ & PEM & $1975-2015$ \\
\hline \multirow{2}{*}{ DO } & PEB & $1975-1990$ \\
& PEB/PEMo & $1990-2005$ \\
& PEB & $2005-2015$ \\
\hline \multirow{2}{*}{ BOD5 } & PEM/PEB & $1975-1993$ \\
& PEB/PEMo & $1993-2015$ \\
\hline
\end{tabular}

It is very complex to explain the multiple factors that play a role in changing water chemistry variation. Barbulescu and Barbes [32] consider that one of the direct consequences of the decrease in water salinity was the modification of the lake biodiversity. Some studies appreciated that the phytoplankton structure was modified during the irrigation period: the number of species diminishing to 14-18 in relation to the previous period, when 38 species were found [21,22,37]. Another indicator is Artemia Salina. A drastic decreasing of Artemia Salina during the irrigation period, compared to the reference period (1952-1960), when densities above $100 \mathrm{~g} / \mathrm{L}$ were recorded [22]. We can conclude that the cause of the increase of BOD5 in the last period (after 1995) could be an increase of aquatic life forms (phytoplankton or/and zooplankton).

\section{Conclusions}

An important aspect of Techirghiol Lake is its potential in the tourism industry, due to its unique properties: saline water and sapropelic mud. The malfunction of environmental protection measures and faulty or insufficient design (period of 1960-1987), in conjunction with the changes in climate has disturbed the normal functioning of the Techirghiol Lake ecosystem, finally resulting in a decrease in its capacity to yield economic values. It is therefore concluded that 1953 is considered as the last year in which the Techirghiol Lake system was under the influence of natural factors and the 1970 year is marked by the passage of the water level to positive values. Starting with 1971, the irrigation system became operational and the ecosystem degradation became aggressive. The rate of salinity decreased as a result of freshwater supply being 1.24\%o during the period of 1970-1987. The period of 1980-1987 is a critical one: overland flow increased (14 times the level of the period of 1953-1970 and the hydrological regime of Biruinta and Urlichioi tributary rivers became permanent); groundwater input increased by 7.2 mil.mc/year over the same period.

The most important challenge in the management of Techirghiol Lake basin is to integrate and balance the interest of the ecosystem and the economy. It is well known that the Dobrogea region is an arid area where crops cannot grow in optimum conditions without irrigation. New investigation in needed to provide the sound, scientific basis in order to find a balance between protecting the ecosystem, increasing the economy and designing hydrotechnical systems in the context of climate change.

Author Contributions: Conceptualization, C.M.; methodology, C.M., C.B. and I.C.P.; validation, C.M., C.B. and I.C.P.; investigation, C.M.; resources, I.C.P. and C.B.; data curation, C.B.; writing-original draft preparation, C.M.; writing-review and editing, C.M., C.B., I.C.P.; visualization, I.C.P.; supervision, C.M. All authors have read and agreed to the published version of the manuscript.

Funding: This research received no external funding.

Acknowledgments: The authors would like to thank the Dobrogea Littoral Water Basin Administration for technical support and National Meteorological Agency-Dobrogea meteorological Center which provided the climatic data.

Conflicts of Interest: The authors declare no conflict of interest. 


\section{References}

1. Shadrin, N.; Zheng, M.; Oren, A. Past, present and future of saline lakes: Research for global sustainable development. Chin. J. Ocean. Limnol. 2015, 33, 1349-1353. [CrossRef]

2. Abbaspour, M.; Javid, A.H.; Mirbagheri, S.A.; Givi, F.A.; Moghimi, P. Investigation of lake drying attributed to climate change. Int. J. Environ. Sci. Technol. 2012, 9, 257-266. [CrossRef]

3. Delju, A.H.; Ceylan, A.; Piguet, E.; Rebetez, M. Observed climate variability and change in Urmia Lake Basin, Iran. Theor. Appl. Climatol. 2013, 111, 285-296. [CrossRef]

4. Valero-Garcés, B.L.; Navas, A.; Machin, J.; Stevenson, T.; Davis, B. Responses of a Saline Lake ecosystem in a semiarid region to irrigation and climate variability: The history of Salada Chiprana, Central Ebro Basin, Spain. AMBIO A J. Hum. Environ. 2000, 29, 344-350. [CrossRef]

5. Webster, K.E.; Kratz, T.K.; Bowser, C.J.; Magnuson, J.J.; Rose, W.J. The influence of landscape position on lake chemical responses to drought in northern Wisconsin. Limnol. Oceanogr. 1996, 41, 977-984. [CrossRef]

6. Ptak, M.; Sojka, M.; Choinski, A.; Nowak, B. Effect of Environmental Conditions and Morphometric Parameters on Surface Water Temperature in Polish Lakes. Water 2018, 10, 580. [CrossRef]

7. Stan, F.I.; Neculau, G.; Zaharia, L.; Ioana-Toroimac, G. The hydrological budget of lakes. Case studies Fântânele and Izvorul Muntelui Reservoirs (Romania). In Water Resources and Wetlands, 4th International Conference Water Resources and Wetlands, Tulcea, Romania, 5-9 September 2018; Gastescu, P., Bretcan, P., Eds.; Romanian Limnogeographical Association: Targoviste, Romania, 2018; pp. 56-63.

8. Salameh, E.; El-Naser, H. Changes in the Dead Sea Level and their Impacts on the Surrounding Groundwater Bodies. Acta Hydrochim. Hydrobiol. 2000, 28, 24-33. [CrossRef]

9. Carrasco, N.K.; Perissinotto, R. Development of a Halotolerant Community in the St. Lucia Estuary (South Africa) during a Hypersaline Phase. PLoS ONE 2012, 7, e29927. [CrossRef]

10. Piovano, E.L.; Ariztegui, D.; Moreira, S.D. Recent environmental changes in Laguna Mar Chiquita (central Argentina): A sedimentary model for a highly variable saline lake. Sedimentology 2002, 49, 1371-1384. [CrossRef]

11. Sojka, M.; Choinski, A.; Ptak, M.; Siepak, M. The Variability of Lake Water Chemistry in the Bory Tucholskie National Park (Northern Poland). Water 2020, 12, 394. [CrossRef]

12. Posea, G. Geomorfologia României-Relief, Tipuri, Geneză, Regionare; (Ediția a 2-a); Fundatia "România de Mâine": Bucuresti, Romania, 2005. (In Romanian)

13. Gastescu, P.; Bretca, P. Aspecte privind starea actuală a lacurilor Siutghiol şi Techirghiol. Analele Universităţii Valahia Târgovişte Seria Geografie 2003, 3, 134-138. (In Romanian)

14. Panin, N. Black Sea coast line changes in the last 10,000 years. A new attempt at identifying the Danube mouths as described by the ancients. Dacia Revue d'Archéologie et d'Histoire Ancienne Bucuresti 1983, 27, 175-184.

15. Gâştescu, P.; Breier, A. Le complexe lacustre Razim-Sinoe (Roumanie). Genèse, Morphométrie et Régime Hydrique; Scritti Geografici in onore di Riccardo Riccardi (Parte I); Società Geografica Italiana: Roma, Italia, 1974; pp. 247-269, (In Italian with French abstract).

16. Maftei, C.; Bărbulescu, A.; Hubert, P.; Serban, C.; Dobrica, G. Statistical Analysis of the Precipitation from Constanța (Romania) meteorological station. In Recent Researches in Applied Computers and Computational Science; Niola, V., Bojkovic, Z., Garcia-Planas, M.I., Eds.; WSEAS Press: Athens, Greece, 2012; p. 52.

17. Zamfirescu, F.; Moldoveanu, V.; Dinu, C.; Pitu, N.; Albu, M.; Danchiv, A.; Nash, F. Vulnerability to pollution of karst system in Southern Dobrogea. In Impact of Industrial Activities on Groundwater-Proceedings of the International Hydrogeological Symposium; Bucharest University Press: Constanţa, Romania, 1994; pp. 591-602.

18. Pascu, R. Cercetari preliminare asupra Lacului Techirghiol (jud. Constanta). Anuarul Institutului Geologic al Romaniei 1910, IV Fasc. I, 1-20. (In Romanian)

19. Planul Naţional de Management Actualizat Aferent Porţiunii din Bazinul Hidrografic International al Fluviului Dunărea Care este Cuprinsă în teritoriul României. Available online: http: //www.rowater.ro/dadobrogea/Planul\%20de\%20Management\%20Bazinal/Plan\%20de\%20Management\% 20actualizat\%20al\%20Fluviului\%20Dunarea,\%20Deltei\%20Dunarii,\%20SH\%20Dobrogea\%20si\% 20Apelor\%20Costiere\%2020162021/ABADL_Planul\%20de\%20Management\%20actualizat\%20TEXT.pdf (accessed on 15 May 2019). (In Romanian). 
20. ORDIN nr. 161 din 16 Februarie 2006 Pentru Aprobarea Normativului Privind Clasificarea Calitatii Apelor de Suprafata in Vederea Stabilirii Starii Ecologice a Corpurilor de apa. Available online: http://www.rowater. ro/dacrisuri/Documente\%20Repository/Legislatie/gospodarirea\%20apelor/ORD.\%20161_16.02.2006.pdf (accessed on 15 May 2019). (In Romanian).

21. Research report MEN Grant 410B/1996. Studiu privind urmarirea parametrilor de calitate si a factorilor care il influenteaza in vederea protectiei resurselor natural ale lacului Techirghiol. 1996; (unpublished work).

22. Research report Grant nr. 587/1986 Consiliul National al Apelor-ICPGA-Cercetari privind evolutia si protectia calitatii apelor lacurilor Techirghiol si Amara in conditiile amenajarilor in curs. 1986; (unpublished work).

23. Bujor, P. Nouvelle contribution á l'étude de la biologie du lac salé du Tékirghiol. In Proceedings of the 5th Congr. Intern. Thalassiothérapie, Iasi, Romania, 23-30 May 1928; pp. 1-85, (In Romanian with French abstract).

24. ABADL Plan de Management-Aria Protejata Lacul Techirghiol 2008-2013 +X Anexe. Available online: http: //www.rowater.ro/dadobrogea/Aria\%20protejata\%20Lacul\%20Techirghiol/Forms/AllItems.aspx (accessed on 15 May 2019).

25. Solomon, S. (Ed.) Intergovernmental Panel on Climate Change (IPCC), Climate Change 2007: The Scientific Basis. Contribution of Working Group I to the Fourth Assessment Report of the Intergovernmental Panel on Climate Change; Cambridge University Press: New York, NY, USA, 2001.

26. Kundzewicz, Z.W.; Robsson, A. (Eds.) Water Detecting Trend and Other Changes in Hydrological Data, WCDMP-45, WMO/TD-No; World Meteorological Organization: Geneva, Switzerland, 2000; p. 1013.

27. Maftei, C.; Barbulescu, A.; Buta, C.; Serban, C. Change points detection and variability analysis of some precipitation series. In Recent Researches in Computational Techniques, Non-Linear Systems and Control; WSEAS Press: Athens, Greece, 2007; p. 232.

28. Maftei, C.; Barbulescu, A. Statistical analysis of precipitation time series in Dobrudja region. Mausam 2012, 63, 553-564.

29. Barbulescu, A.; Maftei, C. Modeling the climate in the area of Techirghiol Lake (Romania). Rom. J. Phys. 2015, 60, 1163-1170.

30. Bărbulescu, A.; Serban, C.; Maftei, C. Statistical analysis and evaluation of Hurst coefficient for annual and monthly precipitation time series. WSEAS Trans. Math. 2010, 9, 791-800.

31. Romanescu, G.; Iosub, M.; Sandu, I.; Minea, I.; Enea, A.; Dascalita, D.; Hapciuc, O.-E. Spatio-temporal Analysis of the Water Quality of the Ozana River. Rev. Chim. (Bucharest) 2016, 67, 42-47.

32. Barbulescu, A.; Barbes, L. Assessment of surface water quality Techirghiol Lake using statistical analysis. Rev. Chim. (Bucharest) 2013, 64, 868-874.

33. ECSN Climate of Europe: Recent Variation, Present State and Future Prospects; KNMI: de Bilt, The Netherlands, 1995; p. 72.

34. Houghton, J.T.; Ding, Y.; Griggs, D.J.; Noguer, M.; Van der Linden, P.J.; Xiaosu, D. (Eds.) Intergovernmental Panel on Climate Change (IPCC) Climate Change 2001: The Scientific Basis. Contribution of Working Group I to the Third Assessment Report of the Intergovernmental Panel on Climate Change; Cambridge University Press: New York, NY, USA, 2001.

35. Maftei, C.; Buta, C.; Draghici, G.; Filip, C. Analysis of changes in hydrometeorological variables of Techirghiol Lake. IOP Conf. Ser. Earth Environ. Sci. 2019, 344, 012025. [CrossRef]

36. Romanescu, G.; Tirnovan, A.; Sandu, I.; Cojoc, G.M.; Breaban, I.; Mihu-Pintilie, A. Water Chemism Within the Settling Pond of Valea Straja and the Quality of the Suha Water Body (Eastern Carpathians). Rev. Chim. (Bucharest) 2015, 66, 1700-1706.

37. Gheorghievici, L.M.; Pompei, I.; Gheorghievici, G.; Tanase, I. The influence of abiotic factors on suppliers of organic matter in the peloidogenesis process from Lake Techirghiol, Romania. Aquac. Aquar. Conserv. Legis. $2012,5,69-78$.

(C) 2020 by the authors. Licensee MDPI, Basel, Switzerland. This article is an open access article distributed under the terms and conditions of the Creative Commons Attribution (CC BY) license (http://creativecommons.org/licenses/by/4.0/). 